Copyright (C) 2021 by Cherkas Global University

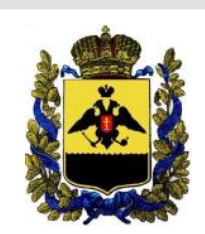

Published in the USA

Bylye Gody

Has been issued since 2006.

E-ISSN: $2310-0028$

2021. 16(4): 2034-2042

DOI: $10.13187 /$ bg.2021.4.2034

Journal homepage:

https://bg.cherkasgu.press

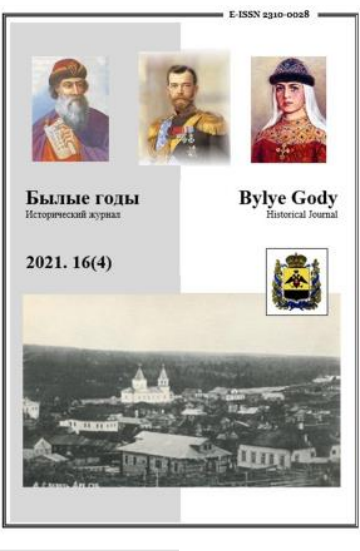

\title{
Sources on the History of the Yenisei Peoples of the Russian Empire (on the Example of the Analysis of Materials from the Newspaper "Krasnoyarets")
}

\author{
Ekaterina A. Sertakova a , *, Alexandra A. Sitnikova a, Yuliya S. Zamaraeva a \\ a Siberian Federal University, Russian Federation
}

\begin{abstract}
The relevance of this study is associated with the importance of studying the history of the indigenous peoples of the north of the Russian Federation, in particular, the Krasnoyarsk krai, which makes it possible to understand the peculiarities of the ethnocultural development of the indigenous peoples of the north from the end of the last century to the present, to see the changes in relations between the Russians and smallnumbered peoples of the north that have occurred over a hundred years old. The significance of the study is explained by the fact that the peculiarities of the life and culture of the northern peoples of the Yenisei province at the beginning of the 2oth century are studied on the basis of materials from «The Krasnoyarets» newspaper, which were not previously considered by scientists. As an archival source for the study 13 issues of «The Krasnoyarets» newspaper were used, which was published in the Yenisei province from 1906 to 1909 , in which feuilletons, articles and notes about the life of the aborigines of the northern territories of the province were published. The main part of the article is the publication of significant extracts and quotes from the newspaper related to the description of the life of the indigenous peoples of the north, with research findings and interpretations. As a result the authors of the article concluded that in newspaper «The Krasnoyarets» journalists are primarily focused on describing the problems of the indigenous population of the Yenisei North - the unfair attitude of merchants to the hunters of the north (to make aborigines drunk with alcohol, low cost of furs exchanged by merchants from hunters, etc.), the spread of destructive diseases among the aboriginal population after contacts with the Russians, the inaccessibility of education for the aborigines, in general, the harsh living conditions in the north, often leading to hunger and other problems. Journalists focus the readers' attention on these problems for the sake of drawing attention to them, for the sake of changing this unfortunate situation in the future.
\end{abstract}

Keywords: indigenous peoples of the north, Yenisei province, newspaper "The Krasnoyarets", Russian press of the early XX century.

\section{1. Введение}

Фонд периодических изданий дореволюционной России в собрании Государственной универсальной научной библиотеки Красноярского края имеет большую историческую и культурную ценность для изучения коренных народов Севера России. В ряде публикаций можно обнаружить не только новостную повестку региона и объявления, но и заметки о жителях отдаленных от крупных населенных пунктов территорий, обычаях проживающих там людей. Такие заметки позволяли жителям Красноярска, Ачинска, Минусинска, а также некоторых других городов и поселков Енисейской губернии (места, где издавались газеты) получать информацию о жизни населения северных территорий губернии и культурных обычаях аборигенного населения Севера и Юга края.

\footnotetext{
${ }^{*}$ Corresponding author

E-mail addresses: sertachok@mail.ru (E.A. Sertakova), sem_dobrianka@mail.ru (A.A. Sitnikova), rybkao8@bk.ru (Yu.S. Zamaraeva)
} 
Освещение вопросов жизни коренного населения Енисейской Сибири в Российской империи осуществлялось через ряд источников. Во-первых, через официальные отчеты и публикации научных сборников деятелей Красноярского подотдела Восточно-Сибирского отдела Императорского Русского географического общества. Информация носила научный характер и была ориентирована преимущественно на просвещенную публику. Публикации выходили в свет после возвращения участников экспедиций и распространялись по подписке. Во-вторых, через средства массовой информации. В газетах и журналах оперативно выходили новости, заметки и статьи, которые освещали данные вопросы для широкой аудитории. Среди них были журналы «Енисейские епархиальные ведомости», «Сибирские вопросы», «Сибирские записки», газеты «Енисейские губернские ведомости», «Красноярец» и др.

Данные периодические издания, за редким исключением, до настоящего времени не были рассмотрены в качестве источников по истории енисейских народов Российской империи.

\section{2. Материалы и методы}

2.1. Ключевыми источниками для исследования аборигенного населения Енисейской Сибири в начале XX века были выбраны материалы, опубликованные в политической, общественной и литературной газете «Красноярец». Это ежедневное издание выходило в свет с 21 октября 1906 по 16 июля 1909 года и распространялось по всей Енисейской губернии. В связи с публикацией нескольких критических материалов о власти газету закрыли по постановлению суда.

Всего в выборку данного исследования вошли материалы четырнадцати номеров. Это источники, опубликованные в №№ 94-95, 97, 151, 203, 265 за 1907 год, в №№ 42, 65, 127-128 за 1908 год и № 11, 22-23, 33 за 1909 год. Именно в этих изданиях встречается информация о коренном населении Енисейской губернии. Поиск осуществлялся по ключевым словам путем работы с оцифрованными газетами.

2.2. Теоретико-методологической базой для изучения материалов, опубликованных в газете, выступили положения исследователя В.М. Рынкова, описанные в статье «Периодическая печать: место в системе исторических источников» (Рынков, 2010). Автор отмечает, что при работе с газетами и журналами, источником для анализа/единицей исследования является не содержание номера целиком, а только колонки текста и даже фрагменты, содержащиеся в них. Автор выявляет значимость и своеобразие отдельного источника, который может дать полезную для исследования информацию. Также внимание при анализе материалов газеты уделялось таким характеристикам, как «информационный потенциал», «категория достоверности», «категория точности» (Доржиева, 2018: 41-42).

При написании данной статьи были рассмотрены концепции формирования этнической идентичности коренных народов России (Амосова и др., 2019; Замараева и др., 2019), систематизированы источники по интересующей теме, проведен анализ текстов и выявлены ключевые моменты, связанные с освещением жизни и положения аборигенных народов в Енисейской губернии.

\section{3. Обсуждение}

Газеты и журналы как источники информации в гуманитарном знании имеют большую значимость. В своих материалах они фиксируют особенности эпохи, культуры, социума и т.д., которые становятся особенно важными в свете осмысления происходящих изменений.

Сибирские периодические издания рассматривались исследователями не часто. Так, новосибирские исследователи В.С. Маркова и И.А. Быкова отмечают, что газетные статьи являются наиболее оперативными источниками, информирующими социум по вопросам истории, культуры и науки Сибири и Дальнего Востока, поэтому их изучение представляется весьма актуальным (Маркова, Быкова, 2000: 346). Отсюда авторы указывают на необходимость составления более обширных библиографий.

Н.В. Жилякова (Жилякова, 2002) рассматривала издание «Сибирская газета» с точки зрения формирования литературно-критической мысли в Томской губернии. Изучив содержание номеров, автор утверждает, что газета стала инструментом формирования регионального самосознания, так как многие материалы были связаны с осмыслением положения человека в Сибири.

Исследователь А.П. Миханев, рассматривая периодическую печать Красноярска периода Российской империи, пришел к выводу, что выпуски газет и журналов оказались «одной из самых ярких реалий своего времени и стали одним из важных факторов, во многом отражавших и определявших политическую, социальную и культурную жизнь Красноярска и Енисейской губернии конца XIX - начала XX века» (Миханев, 1998: 34). В выводах А.П. Миханев отметил, что развитие красноярской периодики было вызвано желанием не только осветить, но и преобразовать жизнь в Енисейской губернии. Именно поэтому в публикациях часто появлялись предложения по реформированию общества через выявление его актуальных проблем.

Внимание к жизни аборигенного населения Енисейской губернии через анализ периодических изданий можно обнаружить в статьях красноярских исследователей. Так, Е.В. Комлева, анализируя 
выпуски «Енисейских губернских ведомостей» конца XIX - начала XX вв., пришла к выводу, что на страницах газеты достаточно полно были отражены сведения о развитии территории Туруханского края и жизни его населения - как аборигенных народов, так и русских поселенцев (Комлева, 2016: 43).

Н.П. Копцева, К.А. Дегтяренко, А.А. Шпак рассмотрели выпускаемый в Санкт-Петербурге журнал «Природа и люди» как достоверный источник по истории северных народов Российской империи. Этнографические материалы, опубликованные в его номерах, затрагивали, в частности, и жизнь народов Севера Енисейской губернии (Копцева и др., 2021).

Исследователи М.А. Колесник, Н.М. Лещинская, Д.С. Пчелкина изучили этнокультурную динамику коренных малочисленных народов Севера в конце XIX - начале XX веков через анализ публикаций в «Енисейских епархиальных ведомостях», так как данный источник содержит большой статистический материал, собранный за несколько десятилетий (Колесник и др., 2021).

В работах, где материалом для анализа выступала дореволюционная пресса, газета «Красноярец» еще ни разу не фигурировала в качестве источника сведений о Енисейской губернии и его населении.

\section{4. Результаты}

На протяжении небольшого периода времени политическая, общественная и литературная газета «Красноярец» выходила в свет под редакцией А.А. Жалудского, Н.В. Скорнякова, В.Н. Полетаева, С.Д. Чадова, Е.К. Жалудской, А.С. Калашникова. Над выпусками работало около двадцати сотрудников. Журналисты подписывали статьи кратко - своей фамилией с указанием инициала имени или еще более кратко - инициалами имени и фамилии без расшифровки, поэтому в тексте настоящей статьи приведены эти краткие данные.

Газета состояла из 4-6 страниц текстового материала. Оформление было простым, иллюстраций и фотографий в ней не предполагалось. Максимум оформления - выделение заголовка крупным и жирным шрифтом (Рисунок 1) и рамки для объявлений за отдельную плату.

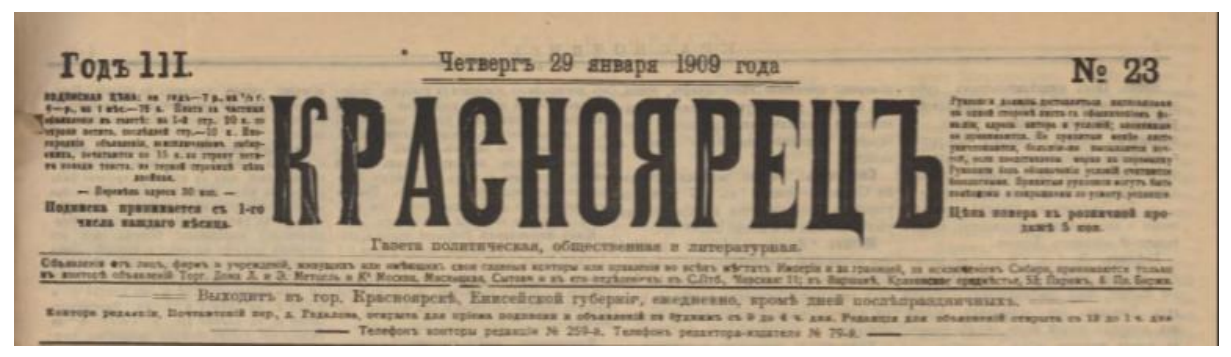

Рис. 1. Заголовок газеты. Из фондов ГУНБ Красноярского края

Темы, освещаемые в номерах газеты «Красноярец», были самыми разными. Материалы, посвященные упоминанию представителей коренного населения Енисейской губернии, встречаются в хрониках, новостях и фельетонах. В фокусе внимания здесь прежде всего - актуальное на момент издания газеты состояние их жизни. Зачастую сведения о жизни в северных поселениях губернии публикуются в рубрике «Фельетон». Стоит отдельно обратить внимание на тот факт, что жанр «фельетон», который сегодня связывают с сатирическими историями, обозначал скорее любой дополнительный контент к основному информационно-политическому содержанию газеты - таким и было изначальное предназначение этого жанра в истории журналистики.

Публикации первых месяцев существования газеты были посвящены преимущественно городской жизни и описанию событий больших сельских поселений, но уже в мае 1907 года начинают появляться колонки, нацеленные на освещение жизни аборигенного населения.

Так, в выпусках № 94 (1 мая), 95 (3 мая) и 97 (5 мая) 1907 года был опубликован большой фельетон М. Шарыпова «Хищники на Хатанге». Материал подан читателю как ряд небольших реальных историй взаимодействия коренного населения и русских купцов. В основе фельетона аллегория: речь здесь идет не о медведях, волках и других реальных хищниках, а о «диком» поведении купцов, приезжающих на Хатангу за пушниной.

«Между тем накачали его водкой до тех пор, пока он не свалился. Они в это время успели еще юрт 5 угостить, обобрать всю пушнину и ничего не заплатить. А когда тунгусы проспались, они уже уплыли дальше вниз по Хатанге» (Шарыпов, 1907с: 2).

«А все-таки с Хатанги всех этих, простите за выражение - купцов выгнать нужно немедленно. Необходимо пока не поздно спасти целое племя первобытных инородцев от физического и нравственного падения и даже гибели. Это племя удивительно склонно ко всевозможного рода заболеваниям, а русские не замедлят заразить их всякими прелестями и тунгусы вымрут в одну неделю» (Шарыпов, 1907с: 2). 
«И я вновь высказываю сожаление, что настоящая статья не могла своевременно появиться в печати» (Шарыпов, 1907b: 2), - автор фельетона сожалеет, что не успел выпустить материал до начала экспедиции г. Макаренко к тунгусам, чтобы тот смог провести с ними ряд профилактических бесед.

Журналисты газеты «Красноярец» получали информацию о проблемах северных народов в процессе профессионального общения с членами Красноярского подотдела Восточно-Сибирского отдела Императорского Русского географического общества или в результате личных поездок на остяцкие и тунгусские ярмарки. Становясь свидетелями и очевидцами неравноправия, существуюего у русских купцов по отношению к аборигенам Севера, журналисты газеты «Красноярец» пытались исправить ситуацию своими статьями.

В газете № 151 (12 июля) 1907 года опубликована новость о научной командировке Константина Михайловича Рычкова на север Енисейской губернии в Туруханский край для изучения племен, населяющих его. Ранее, с 1903 по 1905 годы, он уже проживал в Туруханско-Тазовском крае и занимался изучением самоедов-остяков, юраков и тунгусов, чем внес ценный вклад в науку в области этнографии, антропологии и морфологии. Интересен тот факт, что в газете поездка К.М. Рычкова обозначена как научная командировка, в то время как в других документах указано, что этнограф К.М. Рычков находился в ссылке в Туруханском крае с 1903 по 1913 годы.

«Маршрут командировки г. Рычкова следующий: на пароходе до устья Енисей (долгане), дальше по Анабару, Хатанге и озеро Ессей (тунгусы), затем с р. Хатанги, по побережью Ледовитого океана до Тазовской губы (юраки) и по р. Таз (самоедо-остяки). На поездку эту К.М. Рычков думает употребить два года» (Хроника, 1908: 4).

В газете № 203 (20 сентября) 1907 года опубликован фельетон «Незаметные труженики» статья, в которой рассматриваются тунгусы Приангарского края (Педеко, 1907: 2-3). Их положение сравнивается с тунгусами Енисейской губернии. Говорится, что в обоих регионах аборигенное население находится в одинаково сложных жизненных условиях, по сути, эксплуатируется купцами, ведущими торговлю с аборигенами. В данной публикации также описываются люди, в основном политические ссыльные, которые поддерживают инородцев и помогают им, просвещая в вопросах экономики и пытаясь учить их отстаивать свои права.

В газете № 265 (5 декабря) 1907 года обнаружена запись в колонке «Корреспонденция». Здесь сообщается, что убыль зверя в тайге грозит бродячему населению - тунгусам - гибелью. «Ожесточенное и хищническое истребление зверя со стороны ангарца весною нарушает права собственности тунгусов на звероловные места, утвержденных самим законом, безнаказанное истребление лесов пожарами - порождают среди инородцев голодовки, громадную смертность и угрожают им окончательным вымиранием» (Корреспонденция, 1907: 3).

«Весьма жаль, что сибирская печать не помещает своевременно сведений, касающихся требований рынков на разные сорта шкурок зверей таежного района. Отсутствие здесь телеграфа и неимение положительно никаких заблаговременно данных на требование пушнины всецело ставит зверолова в кабальную зависимость от разных местных Толстых, Башуровых, Пестряковых, Суздалевых, Кокориных и др. «скупщиков» пушнины... обирающих тунгусов при помощи водки, как липку, и в кочевьях, и в сугланных местах» (Корреспонденция, 1907: 3).

В газете № 42 (20 февраля) 1908 года опубликована заметка в хронике об отправлении в Сибирь нескольких научных экспедиций. Антрополог и этнограф Василий Иванович Анучин поехал в Туруханский край для исследования родственных енисейцам (енисейским остякам) племен. Из этой важной для истории этнографических исследований Севера Сибири поездки В.И. Анучин привез сочинение «В стране черных дней и белых ночей: Туруханский край» (Анучин, 1916), которое сопровождается иллюстрациями красноярского художника Д.И. Каратанова. В другой заметке упоминается этнограф Алексей Алексеевич Макаренко, который отправился на Подкаменную Тунгуску к тунгусам. Также в газете указано, что Министерством земельного и государственного имущества снаряжается большая экспедиция в Туруханский край для изучения рыболовства и вопросов лесного рынка во главе с И.К. Окуличем. Сообщается, что в 1908 году большинство экспедиций, инициированных потребностями Российского государства, работало в Енисейской губернии, на Крайнем Севере и Юге (Хроника, 1908: 4).

В газете № 65 (21 марта) 1908 года в хронике освещены темы здравоохранения северных территорий края. Колонка называется «К вымиранию сибирских инородцев», в ней перепечатана телеграмма министра внутренних дел Рачкова из Туруханского края. Он сообщает депутатам Государственной Думы об ужасном положении дел: «Они (инородцы) вымирают целыми чумами. Эпидемия черной оспы распространяется из тундры, род юраков окончательно вымирает» (Влад. Н., 1908: 4).

Автор колонки Влад. Н. отмечает, что содержание телеграммы не является неожиданной новостью, так как тенденция вымирания инородцев Северной Сибири была зафиксирована писателем, общественным деятелем и исследователем Сибири и Центральной Азии Н.M. Ядринцевым значительно раныше (Ядринцев, 1891). Помимо оспы, на территории Туруханского края распространены занесенные русскими людьми цинга, тиф, проказа, сифилис. Отсутствие медицинской помощи делает их очень уязвимыми перед данными болезнями. 
Не только болезни представляют угрозу вымирания коренного населения Севера Сибири, здесь отмечены «постоянные голодовки, порождающие различные формы людоедства, или самоубийства целых племен под влиянием голода». И далее: «Этот каннибализм - не достояние далекого прошлого, а как ни трудно признаться - близкого настоящего нашей северной окраины...» (Влад. Н., 1908: 4).

Для предотвращения вымирания «сибирская группа постановила внести запрос в Государственную думу: известно ли министру внутренних дел о печальной участи инородцев? В настоящее время, когда от Думы нельзя ждать широких реформ в деле самоопределения и защиты инородцев от эксплуататорских тенденций торговцев и самой администрации, подобный запрос заставит лишь русское общество резче реагировать на факты русской действительности» (Влад. Н., 1908: 4).

В газетах № 127 (13 июня) и 128 (14 июня) 1908 года опубликован фельетон об аборигенах Севера. Он состоит из двух дополняющих друг друга материалов - стихотворных напевов и заметки о произошедшей остяцкой ярмарке.

Одно название «грустные» напевы все объясняет. Герои - тунгусы. В тексте сквозит не осуждение, но сочувствие их положению. Указывается ключевая причина этих бед - эксплуатация «младшего брата» купцом.

В описании остяцкой ярмарки автором, который подписывается как В.Б., присутствует много интересных сведений об этносе. Здесь упоминются территория проживания этноса, их традиционные способы хозяйствования, обычаи и привычки, даются определенные наименования вещей (нарты, чум), расценки шкурок зверей и т.д. «Среди инородцев, бродящих по неизмеримым лесам и тундрам Туруханского края, остяки являются, пожалуй, самым значительным обломком обитавших когда-то здесь многочисленных племен Монгольской расы» (В.Б., 1908а: 2).

Ярмарка становится местом, которое помогает выжить остякам, так как «на самой ярмарке купцы все-таки несколько стесняются (их обкрадывать - Авт.) - слишком уж много посторонних глаз», «все остяки состоят в неоплатном долгу у «своих» хозяев, т.е. купцов, выдающих им кредит. У последних установилась уже такая терминология: «это наш остичишко». Но нужно слышать тон, которым произносятся эти слова: так мы говорим только о собаках, да о лошадях» (В.Б., 19о8b: 3). Данные слова выражают вековую зависимость остяков от купцов. Остяки понимают это, но поделать ничего не могут. «Вообще остяки - лакомый кусок не для одних купцов: самая последняя крестьянская баба считает своим долгом пощипать наивных дикарей» (В.Б., 1908b: 3). Бутылка молока - белка, три калача - две белки - такова цена местных крестьян.

Точно такое же отношение к тунгусам: обирают их и купцы с Ангары, ради наживы они держат до них путь 3 месяца.

«Подати остяки платят сравнительно с туруханскими крестьянами большие. С каждого остяка, достигшего 20 лет, в нынешнем году взяли более четырех рублей, тогда как крестьяне платят только около двух» (В.Б., 1908b: 2).

В газете № 11 (15 января) 1909 года напечатана колонка, посвященная школьному образованию в Туруханском крае, который в дореволюционный период территориально занимал 2/3 площади Енисейской губернии, поэтому достаточно часто освещался прессой.

В номере сообщается, что это самая малолюдная территория в северной приполярной полосе мира, включающая «1 заштатный город Туруханск, 4 села и 74 ставки, не считая инородческих чумов. Коренного населения зарегистрировано около 11000 душ, из коего 2/3 составляют аборигены края: остяки, тунгусы, самоеды, юраки, долгане и якуты, ведущие кочевую и бродячую жизнь» (Положение школьного образования..., 1909: 2).

Описывая положение школьного образования, автор сообщает, что на территории расположено пять церковно-приходских школ. При этом две из них - Дудинская и Тазовская - существуют только на бумаге: там нет учеников. В двух Туруханских и Верхнеирбатской обучались 21 мальчик и 29 девочек.

Образование выстроено плохо, учителя малограмотны, а средства для обучения скудны. При этом насущная потребность в грамоте ощущается сильно, местные добровольно выделяют средства для поддержания их работы.

В газетах № 22 (28 января) и № 23 (29 января) 1909 года опубликован фельетон - конспект лекций об остяках Енисейской губернии В.И. Анучина, прочитанных 15 и 17 января в помещении Красноярского общественного собрания по инициативе местного отдела Лиги образования, то есть спустя неделю после научного мероприятия все материалы были опубликованы и доступны широкой общественности. В лекции рассказывается о происхождении названий сибирских инородцев («пегая орда», «остяк», «диньг»), месте их изначального проживания, культуре, быте, промыслах и т.д. Большое внимание уделено теме взаимодействия коренного населения с пришлыми людыми, освещается их современное положение в российском обществе.

«Русское население относится к детям Азии отвратительно, преследуя и выгоняя их с удобных и хороших рыболовных мест. Не редкость - резкие столкновения. На ряду с беспардонной 
эксплуатацией инородцы встречают со стороны русских полное презрение и постоянные обиды» (К-н. Л., 1909а: 2).

Продолжение фельетона «Об Енисейских остяках» связано с рассмотрением физических и психических особенностей племени - двумя типами енисейцев: «Хайньтя» и «Богдейгет». В первом варианте все признаки монгольского начала, во втором - арийского.

«Психический мир енисейца узок и несложен. Енисей для него - центр мира, и все содержание жизни вертится вокруг этой великой реки. Представления о протяжении и величине земли очень ограничены. Весь багаж духовной жизни сведен к эпизодам борьбы за существование и к несложным семейным отношениям» (К-н. Л., 1909b: 2).

Описывается обычай вступления в брак. «Брак енисейцы признают только экзогамный и браков в кругу одного рода не существует. Жениться может лишь достигший 18 летнего возраста, при чем за невесту полагается обязательно калым». Обряд сватовства, венчание шаманом и батюшкой - «бесспорно, что низкий уровень развития является в данном случае причиной двойственности. Каждый родившийся младенец подвергается обряду крещения и таким образом является христианином с колыбели. А параллельно с этим ему дается имя на родном языке, как шаманисту» (К-н. Л., 1909b: 2).

«Заболевания трахома (70 \%), ревматизм, цынга, оспа и сифилис свили себе прочное гнездо среди этих заброшенных детей сурового Севера. При таких условиях вымирание племени идет быстрыми шагами вперед» (К-н. Л., 1909b: 2).

Таким образом, здесь рассматриваются смертность, рождаемость, динамика численности этноса, гражданское устройство (обычное право, суд, воспитание детей, распределение наследства), постройки остяков, утварь, одежда, словесное творчество, верования, пища.

В газете № 33 (13 февраля) 1909 года встречается следующая запись: «Тунгусов иногда накрывают довольно ловко. Дитя здешних лесов, он бьет массу соболей и белок. Сбывать же ему их приходится не приезжим скупщикам, а здешним торговцам, у которых он в большинстве случаев состоит в долгу» (В-ов. И., 1909: 2). В данной статье вновь подчеркивается существующая несправедливость экономических и торговых отношений между коренным населением северных территорий и купцами, организующими торговлю пушниной на этой территории.

\section{5. Заключение}

Анализ источников показал, что тема положения аборигенного населения в Енисейской губернии поднималась в газете нечасто, однако объем текста, в котором освещался данный вопрос, был внушительным и иной раз растягивался на несколько выпусков. Большая часть текстов представлена в жанре фельетона - короткого очерка или статьи, отделенной от других материалов линией отреза. Поскольку жанр «фельетон» в газете «Красноярец» обозначает дополнительный к основному информационно-политическому содержанию газеты материал, то здесь нет никакого сатирического подтекста, напротив, читатель видит, что тема жизни аборигенного населения Севера описана в трагических нотах. Критике подвергаются не аборигены региона, а приезжие.

Важным представляется то, что чаще всего публиковались не литературно-художественные статьи, а сведения научных отчетов, реальных телеграмм, давались репортажи с остяцких ярмарок, публиковались заметки об этнографических экспедициях, то есть достоверные материалы.

Сотрудники газеты «Красноярец», как и в целом русская интеллигенция, проживающая в Енисейской губернии, защищали интересы коренного населения и пытались показать, как не похристиански, бездушно некоторые недобросовестные купцы поступают с представителями коренного населения, которые очень уязвимы и доверчивы. Жизнь их тяжела, и по многим показателям их можно считать несчастными, однако они добры, открыты и незлопамятны, отчего их так легко обмануть, обидеть, обокрасть. В повестке поднимались вопросы необходимости улучшения качества жизни северных этносов: доступа к медицинской помощи, образованию, «честной» торговле. Также журналисты уже в начале XX века высказывали свою обеспокоенность состоянием численности аборигенов Севера Енисейской губернии, находившихся в ситуации крайне тяжелых условий для выживания - болезней, голода, отсутствия гигиены, нехватки продовольствия и многого другого, в результате чего коренное население северных регионов начало значительно сокращаться.

Авторы данных публикаций хотели вызвать общественный резонанс, чтобы подобные практики осуждались и в норму входило человеческое отношение к коренным жителям севера Енисейской губернии, а политика администрации была более внимательна к ним и решению их проблем.

\section{6. Благодарности}

Работа выполнена в рамках реализации проекта РФФИ № 21-о9-43014/21 «"Великое братство народов" (В.Н. Увачан): национальная политика СССР по отношению к коренным малочисленным народам Севера в Эвенкийском и Таймырском национальных (впоследствии - автономных) округах Красноярского края в 1920-1970-е гг.». 


\section{Литература}

Амосова и др., 2019 - Амосова А.А., Копщева Н.П., Ситникова А.А., Середкина Н.Н., Замараева Ю.С., Кистова А.В., Резникова К.В., Колесник М.А., Пименова Н.Н. Этнокультурная идентичность в работах красноярских художников // Журнал Сибирского федерального университета. Гуманитарные науки. 2019. 12 (8). С. 1524-1551.

Анучин, 1916 - Анучин В.И. В стране черных дней и белых ночей (Туруханский край): очерк. Петроград: П.П. Сойкин, 1916. [Электронный ресурc]. URL: http://elib.tomsk.ru/purl/1-8348/

В-ов. И., 1909 - В-ов. И. По губернии // Красноярец. 1909. № 33. С. 2.

В.Б., 1908а - В.Б. Фельетон «Остяцкая ярмарка» // Красноярец. 1908. № 127. С. 2-3.

В.Б., $1908 \mathrm{~b}-$ В.Б. Фельетон «Остяцкая ярмарка» // Красноярец. 1908. № 128. С. 2-3.

Влад. Н., 1908 - Влад. Н. К вымиранию сибирских инородцев // Красноярец. 1908. № 65. С. 4.

Доржиева, 2018 - Доржиева Д.Ц. Особенности информационного потенциала в газетной статье // Гуманитарный вектор. 2018. 13 (5). С. 41-48.

Жилякова, 2002 - Жилякова Н.В. «Сибирская газета», г. Томск, 1881-1888 гг., как явление литературного регионализма: Дисс. ... канд. филолог. наук: 10.01.01 / Наталия Вениаминовна Жилякова; Томск, 2002. 270 с.

Замараева и др., 2019 - Замараева Ю.С., Лузан В.С., Метляева С.В., Середкина Н.Н., Копцева Н.П., Филько А.И., Хребтов М.Я. Религия эвенков: история и современность // Журнал Сибирского федерального университета. Гуманитарные науки. 2019. 12 (5). Р. 853-871.

К-н. Л., 1909а - К-н. Л. Фельетон «Об енисейских остяках» // Красноярец. 1909. № 22. С. 2-3.

К-н. Л., $1909 \mathrm{~b}-$ К-н. Л. Фельетон «Об енисейских остяках» // Красноярещ. 1909. № 23. С. 2-3.

Комлева, 2016 - Комлева E.B. Туруханский край на страницах «Енисейских губернских ведомостей» (вторая половина XIX - начало XX в.) // Научное обозрение Саяно-Алтая. 2016. № 4-5 (16). С. 36-43.

Корреспонденция, 1907 - Корреспонденция // Красноярец. 1907. № 265. С. 3.

Маркова, Быкова, 2000 - Маркова В.С. Быкова И.А. Региональные газеты как источник информации по истории, культуре и науке Сибири и Дальнего Востока (на примере текущих библиографических указателей ГПНТБ СО РАН) / Пятые Макушинские чтения. Тезисы докладов научной конференции, г. Томск. 2000. С. 343-346.

Миханев, 1998 - Миханев А.П. Периодическая печать Красноярска в общественнополитической жизни Енисейской губернии второй половины XIX - начала XX вв.: Автореф. дисс. ... канд. истор. наук: 07.00.02 / А.П. Миханев. Красноярск, 1998. 34 с.

Педеко, 1907 - Педеко. Фельетон «Незаметные труженики» // Красноярец. 1907. № 203. С. 2-3.

Положение школьного образования..., 1909 - Положение школьного образования в Туруханском крае // Красноярец. 1909. № 11. С. 2.

Рынков, 2010 - Рынков В.M. Периодическая печать: место в системе исторических источников // Отечественные архивы. 2010. № 3. С. 44-50.

Хроника, 1907 - Хроника // Красноярещ. 1907. № 151. С. 2.

Хроника, 1908 - Хроника // Красноярец. 1908. № 42. С. 4.

Шарыпов, 1907 - Шарыпов М. Фельетон «Хищники на Хатанге» // Красноярец. 1907. № 94. С. 2-3. Шарыпов, 1907b - Шарыпов М. Фельетон «Хищники на Хатанге» // Красноярец. 1907. № 95. С. 2.

Шарыпов, $1907 \mathrm{c}$ - Шарыпов М. Фельетон «Хищники на Хатанге» // Красноярец. 1907. № 97. С. 2.

Ядринцев, 1891 - Ядринцев Н.М. Сибирские инородцы, их быт и современное положение: этнографические и статистические исследования с приложением статистических таблиц. СПб., 1891. [Электронный pecypc]. URL: http://elib.tomsk.ru/purl/1-8919/

Kolesnik et al., 2021 - Kolesnik M.A., Leshchinskaia N.M., Pchelkina D.S. "Yeniseyskiye Eparkhial'nyye Vedomosti" as a Source of History of the Peoples of the North of the Yenisei Province in the late XIX - early XX centuries // Bylye Gody. 2021. 16(2): 889-897.

Koptseva et al., 2021 - Koptseva N.P., Degtyarenko K.A., Shpak A.A. The Journal «Nature and People» (1910) as a Source of the Peoples History in the Russian Empire // Bylye Gody. 2021. 16(2): 990-999.

\section{References}

Amosova et al., 2019 - Amosova, A.A., Koptseva, N.P., Sitnikova, A.A., Seredkina, N.N., Zamaraeva, Yu.S., Kistova, A.V., Reznikova, K.V., Kolesnik, M.A., Pimenova, N.N. (2019). Ethnocultural identity in the works of Krasnoyarsk artists. Zhurnal Sibirskogo federal'nogo universiteta. Gumanitarnye nauki. 12(8): 1524-1551. [in Russian]

Anuchin, 1916 - Anuchin, V.I. (1916). V strane chernih dnei I belih nochei (Turuhanskyi krai): ocherk. [In the land of black days and white nights (Turukhansk region): an essay]. Petrograd: P.P. Soikin. [Electronic resource]. URL: http://elib.tomsk.ru/purl/1-8348/ [in Russian]

Dorzhiyeva, 2018 - Dorzhiyeva, D.Ts. (2018). Osobennosti informatsionnogo potentsiala v gazetnoy stat'ye [Features of information potential in a newspaper article]. Gumanitarnyy vector. 13(5): 41-48. [in Russian] 
K-n. L., 1909a - K-n. L. (1909). Fel'yeton «Ob yeniseyskikh ostyakakh» [Feuilleton "On the Yenisei Ostyaks"]. Krasnoyarets. 22: 2-3. [in Russian]

K-n. L., 1909b - K-n. L. (1909). Fel'yeton «Ob yeniseyskikh ostyakakh» [Feuilleton "On the Yenisei Ostyaks"]. Krasnoyarets. 23: 2-3. [in Russian]

Khronika, 1907 - Khronika [Chronicle]. Krasnoyarets. 1907. 151: 2. [in Russian]

Khronika, 1908 - Khronika [Chronicle]. Krasnoyarets. 1908. 42: 4. [in Russian]

Kolesnik et al., 2021 - Kolesnik, M.A., Leshchinskaia, N.M., Pchelkina, D.S. (2021). "Yeniseyskiye Eparkhial'nyye Vedomosti" as a Source of History of the Peoples of the North of the Yenisei Province in the late XIX - early XX centuries. Bylye Gody. 16(2): 889-897.

Komleva, 2016 - Komleva, Ye.V. (2016). Turukhanskiy kray na stranitsakh "Yeniseyskikh gubernskikh vedomostey" (vtoraya polovina XIX - nachalo XX v.) [Turukhansk Territory on the pages of "Yenisei Provincial Gazette" (second half of the 19th - early 20th century)]. Nauchnoye obozreniye Sayano-Altaya. 4-5(16): 36-43. [in Russian]

Koptseva et al., 2021 - Koptseva, N.P., Degtyarenko, K.A., Shpak, A.A. (2021). The Journal «Nature and People» (1910) as a Source of the Peoples History in the Russian Empire. Bylye Gody. 16(2): 990-999.

\section{[in Russian]}

Korrespondentsiya, 1907 - Korrespondentsiya [Correspondence]. Krasnoyarets. 1907. 265: 3.

Markova, Bykova, 2000 - Markova, V.S. Bykova, I.A. (2000). Regional'nyye gazety kak istochnik informatsii po istorii, kul'ture i nauke Sibiri i Dal'nego Vostoka (na primere tekushchikh bibliograficheskikh ukazateley GPNTB SO RAN) [Regional newspapers as a source of information on the history, culture and science of Siberia and the Far East (on the example of current bibliographic indexes of the State Public Scientific Technical Library of the SB RAS)]. Pyatyye Makushinskiye chteniya. Tezisy dokladov nauchnoy konferentsii. Tomsk, pp. 343-346. [in Russian]

Mikhanev, 1998 - Mikhanev, A.P. (1998). Periodicheskaya pechat' Krasnoyarska v obshchestvennopoliticheskoy zhizni Yeniseyskoy gubernii vtoroy poloviny XIX - nachala XX vv. [Periodical press of Krasnoyarsk in the social and political life of the Yenisei province in the second half of the XIX - early XX centuries]: avtoref. dis. ...kand. istor. nauk: 07.00.02. A.P. Mikhanev; Krasnoyarsk, 34 p. [in Russian]

Pedeko, 1907 - Padeko (1907). Fel'yeton «Nezametnyye truzheniki» [Feuilleton "Invisible workers"]. Krasnoyarets. 203: 2-3. [in Russian]

Polozheniye shkol'nogo obrazovaniya..., 1909 - Polozheniye shkol'nogo obrazovaniya v Turukhanskom

kraye [Situation of school education in the Turukhansk region]. Krasnoyarets. 1909. 11: 2. [in Russian]

Rynkov, 2010 - Rynkov, V.M. (2010). Periodicheskaya pechat': mesto v sisteme istoricheskikh istochnikov [Periodicals: a place in the system of historical sources]. Otechestvennye arkhivy. 3: 44-50. [in Russian]

Sharypov, 1907a - Sharypov, M. (1907). Fel'yeton «Khishchniki na Khatange» [Feuilleton "Predators on Khatanga"]. Krasnoyarets. 94: 2-3. [in Russian]

Sharypov, 1907b - Sharypov, M. (1907). Fel'yeton «Khishchniki na Khatange» [Feuilleton "Predators on Khatanga"]. Krasnoyarets. 95: 2. [in Russian]

Sharypov, 1907c - Sharypov, M. (1907). Fel'yeton «Khishchniki na Khatange» [Feuilleton "Predators on Khatanga"]. Krasnoyarets. 97: 2. [in Russian]

V-ov. I., 1909 - V-ov. I. Po gubernii [In the province]. Krasnoyarets. 1909. 33: 2. [in Russian]

V.B., 1908a - V.B. (1908). Fel'yeton «Ostyatskaya yarmarka» [Feuilleton "Ostyatskaya Fair"].

Krasnoyarets. 127: 2-3. [in Russian]

V.B., 1908b - V.B. (1908). Fel'yeton «Ostyatskaya yarmarka» [Feuilleton "Ostyatskaya Fair"].

Krasnoyarets. 128: 2-3. [in Russian]

Vlad. N., 1908 - Vlad. N. (1908). K vymiraniyu sibirskikh inorodtsev [Towards the extinction of Siberian aliens]. Krasnoyarets. 65: 4. [in Russian]

Yadrintsev, 1891 - Yadrintsev, N.M. (1891). Sibirskiye inorodtsy, ikh byt i sovremennoye polozheniye: etnograficheskiye i statisticheskiye issledovaniya s statisticheskikh tablits [Siberian foreigners, their way of life and the current situation: ethnographic and statistical studies from statistical tables]. SPb. [Electronic resource]. URL: http://elib.tomsk.ru/purl/1-8919/ [in Russian]

Zamaraeva et al., 2019 - Zamaraeva, Yu.S., Luzan, V.S., Metlyaeva, S.V., Seredkina, N.N., Koptseva, N.P., Fil'ko, A.I., Khrebtov, M.Ya. (2019). Religion of the Evenki: history and modern times. Zhurnal Sibirskogo federal'nogo universiteta. Gumanitarnye nauki. 12(5): 853-871. [in Russian]

Zhilyakova, 2002 - Zhilyakova, N.V. (2002). «Sibirskaya gazeta», g. Tomsk, 1881-1888 gg., kak yavleniye literaturnogo regionalizma ["Siberian newspaper", Tomsk, 1881-1888, as a phenomenon of literary regionalism]: dis. ... kand. filolog. nauk: 10.01.01. Nataliya Veniaminovna Zhilyakova; Tomsk. [in Russian] 


\section{Источники по истории енисейских народов Российской империи (на примере анализа материалов газеты «Красноярец»)}

Екатерина Анатольевна Сертакова а , *, Александра Александровна Ситникова а, Юлия Сергеевна Замараева ${ }^{\text {a }}$

а Сибирский федеральный университет, Российская Федерация

Аннотация. Актуальность настоящего исследования связана с важностью изучения истории коренных народов Севера Российской Федерации, в частности Красноярского края, что позволяет понять особенности этнокультурного развития коренных народов Севера с конца прошлого века до современности, увидеть изменения в отношениях между русскими и малочисленными народами Севера, произошедшие за сто лет. Значимость исследования объясняется тем, что особенности быта и культуры северных народов Енисейской губернии в начале XX века изучаются на основе материалов газеты «Красноярец», которые не рассматривались учеными ранее. В качестве архивного источника для исследования использована газета «Красноярец», издававшаяся в Енисейской губернии с 1906 по 1909 годы. В ее 13 номерах опубликованы фельетоны, статьи и заметки о жизни аборигенов северных территорий губернии. Основная часть статьи представляет собой публикацию значимых выдержек и цитат из газеты, относящихся к описанию жизни коренных народов Севера, с исследовательскими выводами и интерпретациями. По итогам авторами статьи сделан вывод о том, что в газете «Красноярец» журналисты сосредоточены в первую очередь на описании проблем коренного населения Енисейского Севера: несправедливого отношения купцов к охотникам Севера (спаивание алкоголем, низкая стоимость пушнины, вымениваемая купцами у охотников и т.п.), распространения губительных болезней среди аборигенного населения после контактов с русскими, недоступности образования для аборигенов, в целом суровых условий жизни ни Севере, зачастую приводящих к голоду и др. Журналисты акцентируют внимание читателей на этих проблемах ради привлечения к ним внимания, изменения этой неблагополучной ситуации в будущем.

Ключевые слова: коренные народы Севера, Енисейская губерния; газета «Красноярец»; русская пресса начала XX века.

\footnotetext{
${ }^{*}$ Корреспондирующий автор

Адреса электронной почты: sertachok@mail.ru (E.А. Сертакова) 